\title{
Baltimore Steel Stories
}

\section{Abstract:}

The article offers information on the efforts to chronicle the economic and personal changes people have endured in Baltimore, Maryland, to make sense of their lives and represent the contradictions of capitalism which resulted in the media project entitled "Anthropology by the Wire." Topics include the fallout from the closure of one of the last remaining steel plants in the U.S., the contradictions within capitalist logic, and the structural violence that emerges from neoliberal practices.

"Postindustrialism" and "neoliberalism": These terms have become convenient shorthand for shifting strategies of capitalism that have had devastating impacts on cities throughout North America, including Baltimore. But what do these abstractions look like "on the ground"? And how are they negotiated by people living through these wrenching transformations? Over the past five years, we have been working with communities all over Baltimore to chronicle not only the economic and personal changes people have endured but also the efforts of Baltimore residents to make sense of their lives and to represent the contradictions of capitalism to themselves and to others. The result has been a collaborative media project entitled "Anthropology by the Wire," one that engages communities in participatory media all over the city (anthropologybythewire.com) (Figure [NaN] ).

One of the local issues we explore and document with our collaborators in Anthropology by the Wire is the fallout from the closure of one of the last remaining steel plants in America at Sparrow's Point in Baltimore. As anthropologists engaging in participatory media, we enter into a crowded representational field, one where multiple actors and institutions produce multiple media imbued with different degrees of authority. Our work with former employees of the steel mill at Sparrow's Point is a case in point: Many former employees, neighborhood residents, academics, and documentarians have chronicled the agonizing fall of the plant with 
photography, film, and prose. It is both symbolic and synecdoche for Baltimore and for the postindustrial city in general (Figure [NaN] ).

One form of representation we are currently undertaking is to create an offshoot of Anthropology by the Wire called Baltimore Steel Stories to document a form of critical nostalgia taking place through photo-elicitation with retired steelworkers. In 2013, we were given hundreds of old photographs that were taken and collected over the years during events at the Steelworkers Union Hall. Found in a safe, the photos and other ephemera capture meetings, parties, activism, and a variety of other anecdotal activities in and around this epicenter of industrial life throughout the latter 20th century until the closure of the plant. Here, nostalgia allows people to create a space for critique amidst the destruction of the actual space of their labor; simultaneously, nostalgia recenters discourse on the postindustrial as primarily about workers, their lives, and their families rather than the reports on profits and the ruinous movement of capital (Figure [NaN] ).

In the case of the closing of the Sparrows Point steel mill and the union-shop it hosted, we observe one of the inherent contradictions within capitalist logic, and one that is becoming more and more pronounced as it extends further with each new round of free trade agreements. Specifically, it is a logic where workers and regions are supposed to specialize in a certain skill or industry, yet a rapidly changing marketplace is the norm. In the case of Sparrows Point, workers honed their skills over the course of a career, increasing the productivity of the plant over and over again. In the end, though, their own specialization limited their flexibility in a job market that prizes creative destruction above all else. This destruction, literal and not creative, saw steel production shift away from industrial centers in the rust-belt states, where steel made by American-owned companies and the labor of the United Steelworkers established long-standing control over the global market for steel. With technological shifts and the expansion of credit, the flexibility and speed of capital increased exponentially. International trade and banking institutions replaced America's hegemonic position in the world's political economy. This new arrangement allowed for new conglomerates of concentrated capital to form. Simultaneously, the flexible nature of capital combined with the power of global institutions makes it possible for steel manufacturing to steadily move to the global south, where colonial legacies create conditions where people are exploited to work for less, as these new multinational companies continue to increase their surpluses and profits (Figure [NaN] ).

In our project, we document the structural violence that emerges from neoliberal practices. Both critical and cognizant of these new accumulation strategies, many of our participants note the increasing scope of corporate power and the dissolution of state power. At one time, the United Steelworkers strategically relied on the power of the state to give them more bargaining power in their attempt to establish a buffer between the individual workers and the company that wished to increase surpluses extracted from workers' labor. But that has all been upended, and the state, as participants note, has become the servant to global capital through the massive restructuring of the global steel industry ushered into place by trade agreements and global financial entities. Today, the steel factory is gone, and the property, on the periphery of Baltimore, with access to a deep water port, is subject to numerous plans for redevelopment. This "Civilization of Sparrows Point," as oneof our collaborators referred to it, has joined the ranks of Baltimore's deindustrialized periphery. Working with Baltimore's steelworker community, we observe how the macro effects of neoliberalism take on literal and localized forms.

The participants in our fieldwork project are well aware of the violence that is inherent in capitalism and exacerbated by neoliberalism in the modern era. This violence is apparent in the daily lives of steelworkers, whether it is the loss of fictive kin ties or the concomitant loss of physical and mental health. Although this is true for most former steelworkers, some are affected more than others. While many of the younger former 
steelworkers are able to shift their skill sets to other industries or other service sector jobs, the union retirees and steelworker elders have been most notably hit the hardest by the initial shutdown of the steel plant and the subsequent deindustrialization of the steelworker community thereafter (Figure [NaN] ).

Much of the harm experienced by the retirees came when many lost their company-provided healthcare with the initial shutdown of Bethlehem Steel. While the union was portrayed to be, and sometimes certainly was, antagonistic to the company and management, a hierarchy of paternalism still persisted. This paternalism is now most notably characterized by the health insurance provided by the company. Historically, this was a conscious decision of the national USW, as an alternative to government provided healthcare, and the USW locals of Sparrows Point naturally followed suit. This is important because it runs counter to traditional stereotypes and representations of unions as corrupt and criminals, cast by popular media, such as The Wire. What we observed in our fieldwork was largely quite the opposite: The United Steelworkers union chose to honor their contract and agreement, while Bethlehem Steel did not. This legacy of the USW's reliance on and subsequent violent severance from the company also helps us to shed light on the impacts of Obama's sweeping healthcare reforms, which drastically impacts the insurance of most retirees (Figure [NaN] ).

These reforms were neoliberal in their own right, as many of them benefited private insurance companies. President Obama's focus on healthcare instead of the failing national economy was already seen as a betrayal by many steelworkers, the retirees in particular. This is mostly the reason for the steelworker community's official political shift from left to right in the last decade, a first for this community. The elder steelworkers were dispossessed of their health as they were simultaneously dispossessed of their jobs, fictive-kin relations, and middle-class standard of living. According to the logic of neoliberalism, this was a necessary and even progressive result. Because of their age, the retirees are no longer able to aid in the process of creative destruction that is supposed to drive capitalism forward. Toward the end of the last century, facing already shrinking numbers, and no longer able to lean on their allies, much of the former Sparrows Point steel workers are victims of these changes, although certainly not passive (Figure [NaN] ).

Our main collaborators in Baltimore Steel Stories are Local 9477 retirees in Baltimore, representing a combination of the two biggest locals (2609 and 2610). We employ onsite photo elicitation using the Baltimore Steel Stories web archive and build rapport by casting the digitized photos and ephemera on a slideshow that plays before the official meetings. Many of the active union retirees remember America's manufacturing industry with nostalgia. The fact that many of the photos are from the "glory days" of Sparrows Point, along with steel production in general, helps to engage the participants who can identify with the economic and cultural high point of the "Civilization of Sparrows Point." Often, the retirees are preoccupied with their degrading health, funding for the local, and concerns for the well-being of the next generation. At almost every union meeting, sincere fears over national security are also a primary concern, given many retirees' experience as veterans, who are quick to point out that America no longer has its own source of steel, a critical commodity during wartime. Despite these challenges, it is not uncommon for former steelworkers to serve as autohistorians of Baltimore's steelworker and union history. It is a history that continues to become more complicated and dense as we continue our work with Baltimore Steel Stories (Figure [NaN]).

Graph: Former steelworker Mr. Kevin Cooper views video footage and gives participatory feedback on his recorded interview. Anthropology by the Wire fieldwork photo June 2013. Photographer: Matthew Durington.

Graph: "A Bygone Era," breaking ground for the Union Hall in Baltimore. From the Union Hall Photo Archive.

Graph: "Labor at the Mill Diversifies," black steelworker from Sparrows Point. From the Union Hall Photo Archive. 
Graph: "Alienation in an Economy of Scale," shot of the Steel Mill. From the Union Hall Photo Archive.

Graph: "Multiculturalism expressed in Union Representation," Steel 1980 Pamphlet. From the Union Hall Photo Archive.

Graph: "A Healthy Paternalism," dental plan flyer. From the Union Hall Photo Archive.

Graph: "Division of Labor," shot of Mr. Gordon Johannes at the June 2015 retirees luncheon. Photographer: Bill Barry.

Graph: "Grief," graffiti on a rail car at the former steel plant as it is being demolished. Photographer: Cameron Rines. 